\title{
Instagram: A Platform for English Learning or English Language Business?
}

\author{
Irmawan Rahyadi ${ }^{1}$, La Mani $^{2}$, Abdul Razak Mozin ${ }^{3}$, Zakirah Tamimi $^{4}$ \\ \{irmawan.rahyadi@binus.edu'1, lamani@binus.edu ${ }^{2}$, zack@binus.ac.id ${ }^{3}$, \\ tamimi.zakirah001@binus.ac.id $\left.{ }^{4}\right\}$ \\ Communication Department, BINUS Graduate Program - Master of Strategic Marketing \\ Communication, Bina Nusantara University, Jalan Kebon Jeruk No. 27, Jakarta Barat 11530, DKI \\ Jakarta, Indonesia ${ }^{1,2,3,4}$
}

\begin{abstract}
This study aimed to assess the proportion of establishing and running Instagram content using \#belajarbahasainggris, which translates to \#learningEnglishlanguage. We also aimed to determine the English learning content and English language business. The article used the \#belajarbahasainggris hashtag in the search feature in the Instagram application to locate and identify 362.089 posts. The report then analyzed and classified the first 100 posts into being either educational or marketing content. Marketing content signifies educational content that implicitly or explicitly encourages the public to buy a product or service even though it looks like educational content. The analysis found that the majority of the content was marketing content. It acknowledges the media literacy of the stakeholder in Indonesia who prefer to consume educational content compared to marketing content. Further research is needed to evaluate the effectiveness of this interactivity against other types of academic content initiatives in social media.
\end{abstract}

Keywords: Instagram, English language, English language learning, hashtag, marketing content.

\section{Introduction}

There has been a surge of interest in English language learning in Indonesia during the last decades since English is a compulsory subject in Indonesia [1]. However, the reality is not as promising as Indonesia falls behind other non-English speaking countries; Indonesia is ranked low at 74 out of 100 countries [2]. English language for Indonesian continues as an important language for business, technology, and education. One of the languages earning platforms for modern learners is social media which relates to the technological advancement in Indonesia with 170 million social media users [3] since Indonesians are early adopters of technology [4], smartphone as the primary device to access social media [5]-[7].

In Indonesia, at least four social media platforms have been utilized as communication space for various aspects of Indonesian society; politics, social, religion, business, and information sharing [8], [9]. Instagram falls under the image and video social networking sites, and most of the posts contain a stream of photographs documenting and exhibiting the user's daily life [10]-[12]. Also, Instagram has been used as an educational and knowledge acquisition source [13]. Unfortunately, resources readily accessible by users in Instagram has created promising marketing and advertising space as well which diluted the educational content for 
users who has educational motive using Instagram. Using Instagram with knowledge acquisition motives positively affects social media use when analyzing and studying social media. In addition, most studies in social media impact the unappreciated positive side of the discussion while underlining the fact that social media is underutilized and the negative side [14]-[16]. The drive to pour more positive content while negative, hoax, and ethical violation content competing have undoubtedly led to trust in users searching for knowledge, information, and inspiration in Instagram, consequently extending their existence. One of the knowledges gained from social media is language learning. Indonesians learn English as a second language from social media as Instagram utilized photos and videos as the prominent underlining uniqueness.

The main objective of this study was to assess the proportion of educational content in the English language compared to English language marketing and advertising content. Additionally, several hashtags were analyzed to validate content concentrations.

\section{Research Methods}

A data selection of several specific hashtags was conducted at the Instagram search feature, which is the primary function of gathering posts from this social media platform. Hashtags were preferred to collect the possibly sizable volume of content using Indonesian words; \#belajarbahasainggris (learn the English language), \#belajarenglish (learn English), and \#belajarbahasainggrismudah (learn the English language easy). \#belajarbahasainggris hashtag was chosen because of the most significant volume of posts (362.089 posts). This data-gathering process was finalized in June 2021. The total data then were reduced to 100 first posts. Data were categorized for educational content and marketing content and followed up to the analysis process.

Analysis of data categorized video and photo posts into business and educational content against academic standards according to the credibility of sources [17]. While marketing content was posted by an institution or person who sells products or services related to English language products, educational content was mainly posted by a peer who has skills or sharing the educational journey with other Instagram users. The first 100 posts were collected from the standard Instagram search feature where it divides into the recent and top posts. This study explored the recent section post, started from June 30, 2021, and continued to later posts until 100 posts were collected and analyzed.

\section{Results and Discussion}

One hundred posts were able to generate a consensus that content is divided into two categories according to the aim of the study. In contrast, the data analysis found of the 100 \#belajarbahasainggris posts, 23 were educational, and 77 were categorized as business content. The systematic breakdown of the first 100 posts can be viewed in Table 1 . The posts were a mix of video and photo posts. The type of the post varies from introductory photo post and carousel. Video posts mostly covered a closeup of a person while explaining a specific English language topic in Indonesian. This study gave a picture of a category that describes which positions can be consumed by Instagram users for education and which posts might be educational and contain marketing purposes. 
Table 1. Data from the first 100 posts from \#belajarbahasainggris.

\begin{tabular}{lll}
\hline Post & Quantity & Details \\
\hline Marketing content & 77 & Sell product/service \\
Educational content & 23 & Post educational \\
& & content without \\
& & selling any product or \\
& service r
\end{tabular}

Good use of Instagram features by content creator using the hashtag \#belajarbahasainggris was the carousel, video, stories, and hyperlink username. The intention of getting views and likes made the content creators used all the features available. A carousel is a post on Instagram where users can place multiple photos or videos in one position and can be viewed by swipe and click the left button on the seat. While video post can be identified by a button-shaped as filled triangle arrow facing right located at the top right or middle of thumbnail referring to play button, the carousel post can be identified by a button-shaped as two filled squares stacked on top of each other. The video post can be seen in Figure 2 and the primary photo post in Figure 3. The introductory photo post does not have any button on the post thumbnail. As seen in Figure 1 , the carousel post typically can be swiped left or clicked next arrow to open the following content in the center.

This carousel is used widely in the data where content creators can finish one topic as a comprehensive learning material in one post. Diverse topics used carousel post including word of the week; daily habit led to English acquisition, word synonym, slang words, article, action verbs, and many more.

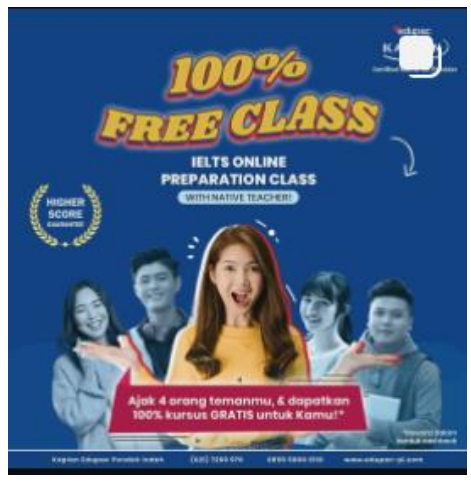

Fig. 1. Carousel post. 


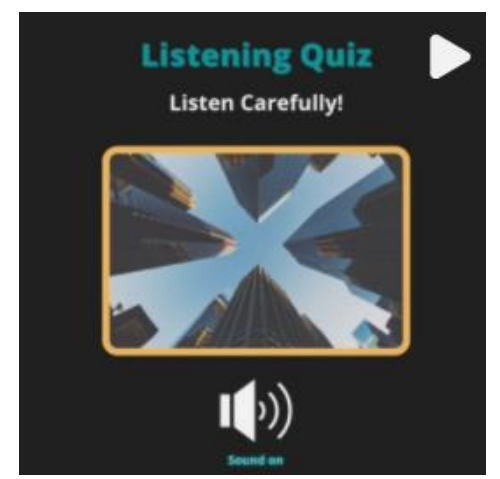

Fig. 2. Video post.

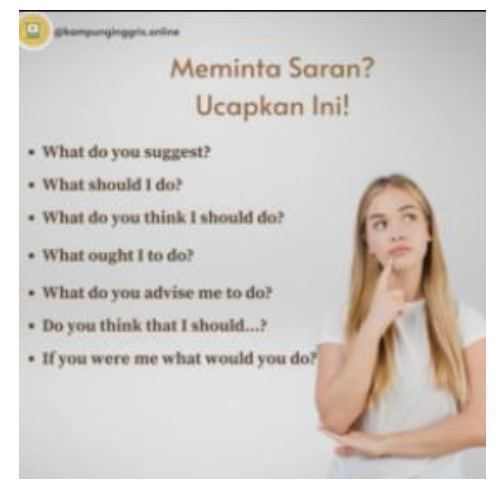

Fig. 3. Basic photo post.

\subsection{Marketing content}

This study indicates that marketing content is the majority of collected data-marketing content in this context aimed to encourage other users to buy products or services offered. Through enticing content with the right image, design, and logo, educational information is also used more often as the soft selling approach. However, the marketing content is categorized from academic content, looking at the content sources from their username, bio, and a sales pitch in the post. For example, a username, @agc_ourse, might sell an English course, but the analysis stage digs deeper into their bio section and another post.

This study confirms that marketing content usual marketing content, including educational information, are adapted to their posts. Then, marketing content reported information associated with product and service from the institution or language firm, allowing the other users to point out that data mostly leads to buying a product or service. This study result suggests that for some 
Instagram users, marketing content is a blatant sales pitch. Creating exciting content that inviting views is the skills and creativity demanded by literate social media users and one of the benchmarks that will win the business area's competition. Most marketing contents used attractive graphic design and a well-thought layout. In terms of marketing content using educational information, the data shows that Instagram business account in this niche applied more informational content that explicitly stated the product or service they sell with a more hard selling approach.

\subsection{Educational content}

Integrating the findings from this study, the data suggest that educational content within the \#belajarbahasainggris hashtag in Instagram most reinforced the posts showing individuals or institutions without selling any English product or service contributing to the overall content. A few posts where random accounts used this hashtag to engage with the niche contributed to incidental unrelated English language learning. There was even a foreign account with questionable intentions that used the hashtag. Also, none of the posts categorized in educational content sell any English language learning product or service. Nonetheless, the hashtag has been famous as a social media marketing strategy to get the view as an engagement in the business niche. Finding business intention in educational content, one may conclude that Instagram content is relatively open to business and social approach, but have no single categorize when content creator aiming to gain engagement from other Instagram users. Data shows that educational content used more video as a speaker explaining an English language learning topic.

\section{Conclusion}

To conclude, this study found that marketing content used educational information in inviting Instagram users to view their content. This study sheds new light on the phenomenon of foreign language learning from social media platforms. This data reveals that the affordances of social media content deliver a convenient space for Instagram users to learn English via material provided by the content creator, whether they are business-oriented or social-oriented. According to this study, exciting content with enticing graphic design is mainly created by business intention, while educational content mostly used video.

However, social media literacy (which was referred to as understanding the benefit) cannot be detected via this study. Taking the categories (marketing and education) in this study, this is one of the studies that explore the data quantitatively to address the availability and the question of positive and negative content in the social media realm. Thereby, these findings contribute to how Instagram users offer a specific range related to English language learning. A further investigation of this research scope might be directed towards how effective educational content that consumed by Instagram users who have different motives.

\section{References}

[1] A. Lauder, "the Status and Function of English in Indonesia: a Review of Key Factors," Makara Hum. Behav. Stud. Asia, vol. 12, no. 1, p. 9, 2008, doi: 10.7454/mssh.v12i1.128.

[2] Education First, "EF English Proficiency Index," 2020. .

[3] S. Kemp, "Digital in Indonesia: All the Statistics You Need in 2021 - DataReportal - Global 
Digital Insights," 2021. .

[4] YouGov, "YouGov $\mid$ A third of Indonesians are early adopters of technology, predominantly young, well-off married men," 2020. .

[5] R. Dekker, G. Engbersen, J. Klaver, and H. Vonk, "Smart Refugees: How Syrian Asylum Migrants Use Social Media Information in Migration Decision-Making," Soc. Media Soc., vol. 4, no. 1, Jan. 2018, doi: 10.1177/2056305118764439.

[6] J. Ohme, M. M. P. Vanden Abeele, K. Van Gaeveren, W. Durnez, and L. De Marez, "Staying Informed and Bridging 'Social Distance': Smartphone News Use and Mobile Messaging Behaviors of Flemish Adults during the First Weeks of the COVID-19 Pandemic," Socius Sociol. Res. a Dyn. World, vol. 6, p. 237802312095019, Jan. 2020, doi: $10.1177 / 2378023120950190$.

[7] D. C. S. James and C. Harville, "Smartphone Usage, Social Media Engagement, and Willingness to Participate in mHealth Weight Management Research Among African American Women," Heal. Educ. Behav., vol. 45, no. 3, pp. 315-322, Jun. 2018, doi:

10.1177/1090198117714020.

[8] Statcounter, "Social Media Stats Indonesia | StatCounter Global Stats," 2021.

[9] M. Lim, "Freedom to hate: social media, algorithmic enclaves, and the rise of tribal nationalism in Indonesia," Crit. Asian Stud., vol. 49, no. 3, pp. 411-427, 2017, doi: 10.1080/14672715.2017.1341188.

[10] D. O'Connell, “\#Selfie: Instagram and the United States Congress,” Soc. Media Soc., vol. 4, no. 4, Oct. 2018, doi: 10.1177/2056305118813373.

[11] J. D. Boy and J. Uitermark, "Lifestyle Enclaves in the Instagram City?," Soc. Media Soc., vol. 6, no. 3, Jul. 2020, doi: 10.1177/2056305120940698.

[12] V. O'Meara, "Weapons of the Chic: Instagram Influencer Engagement Pods as Practices of Resistance to Instagram Platform Labor,”Soc. Media Soc., vol. 5, no. 4, Oct. 2019, doi: $10.1177 / 2056305119879671$.

[13] M. Fidan, M. Debbağ, and B. Fidan, "Adolescents Like Instagram! From Secret Dangers to an Educational Model by its Use Motives and Features: An Analysis of Their Mind Maps," $J$. Educ. Technol. Syst., vol. 49, no. 4, pp. 501-531, Jun. 2021, doi: 10.1177/0047239520985176.

[14] B. Li, S. Stokowski, S. W. Dittmore, and O. K. M. Scott, "For better or for worse: The impact of social media on Chinese sports journalists," Commun. Sport, vol. 5, no. 3, pp. 311-330, Jun. 2017, doi: 10.1177/2167479515617279.

[15] G. Garofolo, S. D. Akinleye, E. J. Golan, and J. Choueka, "Utilization and Impact of Social Media in Hand Surgeon Practices," Hand, vol. 15, no. 1, pp. 75-80, Jan. 2020, doi: $10.1177 / 1558944718787285$.

[16] N. Hajli, "A study of the impact of social media on consumers," Int. J. Mark. Res., vol. 56, no. 3, pp. 387-404, 2014, doi: 10.2501/IJMR-2014-025.

[17] Y. L.-J. of E. T. D. and and undefined 2010, "Social media tools as a learning resource," aquila.usm.edu, vol. 3, no. 1, pp. 101-114, 2010, doi: 10.18785/jetde.0301.08 